DOI: $10.19195 / 2300-7729.35 .8$

\author{
OLIMPIA MAtECKA \\ MARIUSZ POLARCZYK \\ Biblioteka Główna i Centrum Informacji Naukowej \\ Uniwersytetu Przyrodniczego w Poznaniu
}

\title{
Miejsce i zadania Biblioteki Głównej Uniwersytetu Przyrodniczego w Poznaniu w układzie uczelnia-System Informacji o Szkolnictwie Wyższym POL-on
}

\section{Wstęp}

Biblioteka Główna i Centrum Informacji Naukowej Uniwersytetu Przyrodniczego w Poznaniu (zwana dalej Biblioteką Główną) stanowi podstawę systemu biblioteczno-informacyjnego uczelni. Poza Biblioteką Główną w skład tego systemu wchodzą również biblioteki filialne oraz specjalistyczne. Do jednych z podstawowych zadań Biblioteki Głównej określonych w statucie uczelni należy „prowadzenie bibliografii, w tym ewidencji dorobku naukowego i dydaktycznego pracowników i doktorantów” oraz „zapewnienie dostępu do bieżącej informacji naukowej"1. W celu realizacji tych zadań w 2006 r. Biblioteka Główna zakupiła system bibliograficzno-bibliometryczny Expertus firmy Splendor. Dwa podstawowe moduły umożliwiły rejestrację opisów bibliograficznych oraz utworzenie bazy danych, która została udostępniona na stronie domowej Biblioteki Głównej ówczesnej Akademii Rolniczej (rys. 1).

${ }^{1}$ Statut Uniwersytetu Przyrodniczego w Poznaniu. Załącznik do uchwały Senatu UP w Poznaniu nr 112/2006 z dnia 30 czerwca 2006 r. (z późn. zm.), http://portal.puls.edu.pl/sites/default/files/ Statut\%20tekst\%20jednolity.pdf [dostęp: 13.07.2016]. 


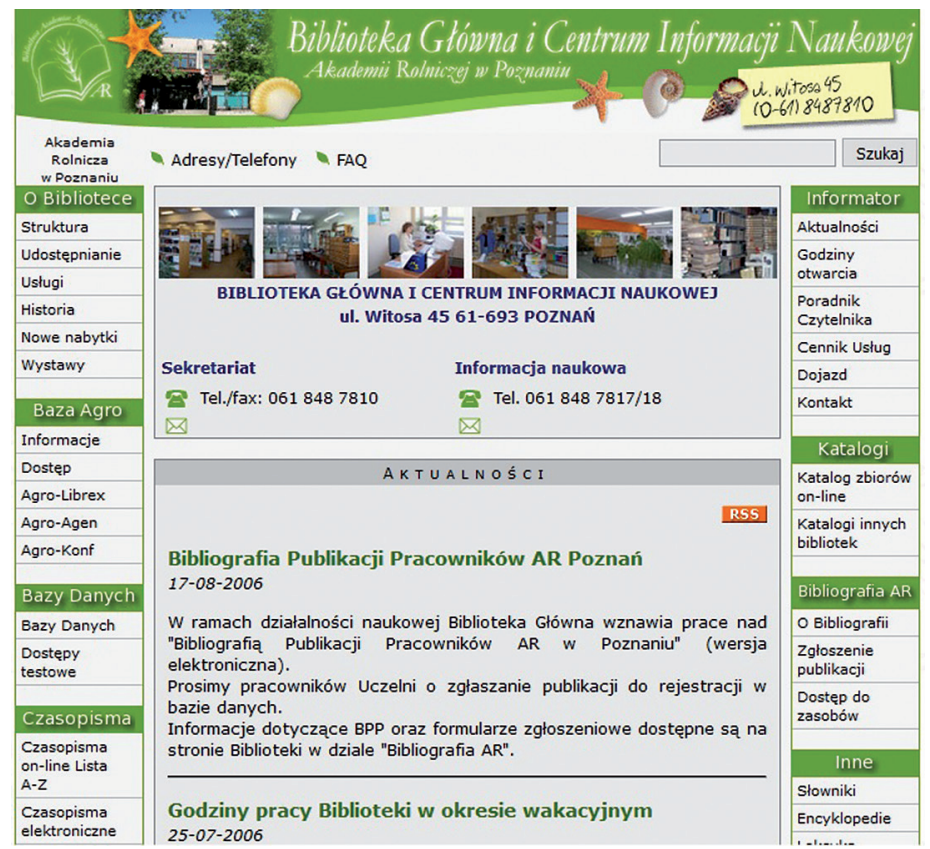

Rys. 1. Informacja o bazie na stronie domowej Biblioteki Głównej AR Poznań

Źródło: http://bg.au.poznan.pl/ [dostęp: 21.08.2006].

Na skutek wprowadzanej reformy systemu nauki i szkolnictwa wyższego zmianom ulegały zadania realizowane przez Bibliotekę Główną. Istotne znaczenie miało uruchomienie w drugiej połowie 2012 r. Polskiej Bibliografii Naukowej (PBN), stanowiącej część Systemu Informacji o Szkolnictwie Wyższym POL-on. Pierwsze i najobszerniejsze prace dostosowawcze do zmieniających się przepisów zostały przeprowadzone w bazie Bibliografia publikacji pracowników Uniwersytetu Przyrodniczego w Poznaniu.

\section{Baza Bibliografia publikacji pracowników}

Powstająca od 2006 r. baza Bibliografia publikacji pracowników tworzona jest przez zespół pracowników Oddziału Informacji Naukowej Biblioteki Głównej. Stanowi ona kontynuację wydanych 4 tomów bibliografii publikacji pracowników naszej uczelni, obejmującej lata 1945-1965, 1966-1970, 1971-1975 i 1976-1980. Baza ta dokumentuje prace wydane po roku 1980, których autorami są pracownicy, doktoranci i pracownicy emerytowani Akademii Rolniczej i Uniwersytetu Przyrodniczego w Poznaniu. Na jej potrzeby w drugiej połowie 2005 r. w oparciu o normy bibliograficzne zostały opracowane formaty opisów dotyczące: publikacji w wydawnictwie ciągłym, wydawnictwa zwartego, fragmentu wydawnictwa 
zwartego, recenzji w wydawnictwie ciągłym, patentu, dokumentu elektronicznego o dostępie lokalnym, fragmentu dokumentu elektronicznego o dostępie lokalnym, dokumentu elektronicznego o dostępie zdalnym i jego fragmentu. Podstawowe elementy opisu bibliograficznego mogą zostać uzupełnione słowami kluczowymi, linkiem do pełnego tekstu, punktacją czy wartością wskaźnika Impact Factor. Zarejestrowane dane są pogrupowane w odpowiednie indeksy, np. autorski, słów kluczowych czy tytułów czasopism, służące przeszukiwaniu bazy. Wraz z udostępnieniem bazy na stronie Biblioteki Głównej uruchomiono formularze zgłoszeniowe w formacie .doc i .odt oraz formularze www. Umożliwiały one dokonywanie zgłoszeń trzech podstawowych typów publikacji drogą elektroniczną (rys. 2).

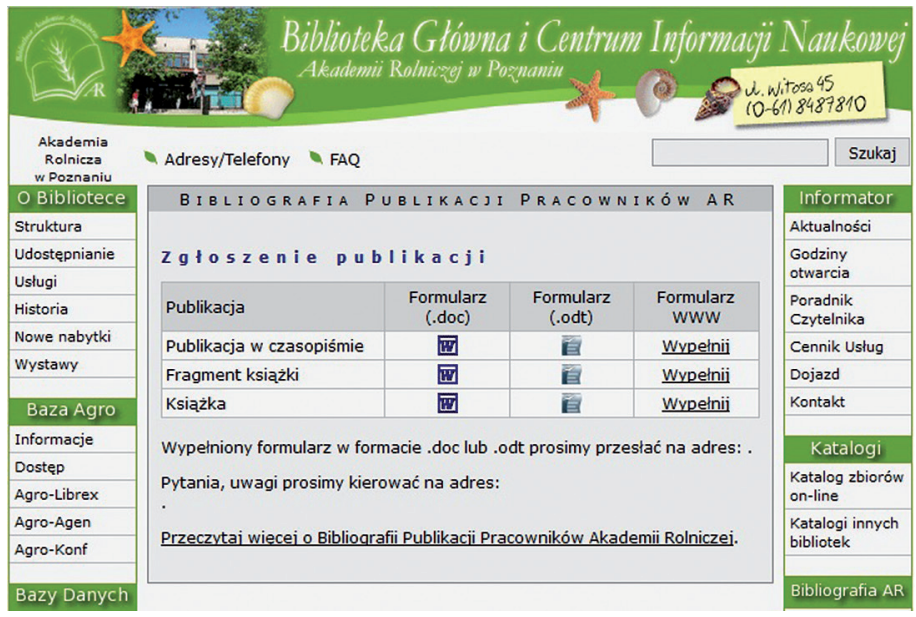

Rys. 2. Dostęp do formularzy zgłoszeniowych ze strony Biblioteki Głównej

Źródło: http://bg.up.poznan.pl/bg/dzialy/bibliografia/zgloszenie_publikacji.php [dostęp: 21.08.2006].

Według przyjętych założeń dokumentacyjnych w bazie Bibliografia publikacji pracowników rejestracji podlegają różnego rodzaju publikacje, np. artykuły z czasopism naukowych i fachowych, monografie, podręczniki, rozdziały w pracach zbiorowych czy publikowane materiały konferencyjne. Ze względu na duży przedział czasowy baza została umownie podzielona na dwie części:

- bibliografia retrospektywna (lata 1981-2004),

- bibliografia bieżąca (publikacje od roku 2005).

W latach 2006-2012 gromadzeniu i rejestracji danych podlegały materiały dobrowolnie zgłoszone przez pracowników lub znajdujące się w zasobach Biblioteki. W tym okresie przyrost danych był nieduży i następował powoli.

Na początku 2013 r. z inicjatywy Biblioteki podjęto rozmowy z władzami uczelni na temat rozszerzenia funkcjonalności bazy Bibliografia publikacji pracowników. Do spotkania przyczyniły się: 
—uruchomienie Polskiej Bibliografii Naukowej, której przedstawiciel w końcu grudnia 2012 r. zwrócił się listownie z prośbą o umożliwienie zaimportowania danych z naszej bazy do PBN ${ }^{2}$,

— ocena jednostek za lata 2009-2012 według Rozporządzenia Ministra Nauki i Szkolnictwa Wyższego z dnia 13 lipca 2012 r. w sprawie kryteriów i trybu przyznawania kategorii naukowej jednostkom naukowym.

W lutym 2013 r. na spotkaniu z rektorem, prorektorami i przedstawicielami wydziałów Uniwersytetu Przyrodniczego w Poznaniu przedstawiono aktualny stan bazy, system gromadzenia i opracowywania danych oraz proponowane rozwiązania w zakresie dostosowania bazy do aktualnych przepisów. W wyniku kolejnych spotkań roboczych z prorektorem ds. nauki i współpracy z zagranicą oraz pracownikami Działu Nauki opracowane zostały nowe formularze zgłoszeniowe dostosowane do obowiązującego systemu oceny parametrycznej jednostek (według Rozporządzenia Ministra Nauki i Szkolnictwa Wyższego z dnia 13 lipca 2012 r.) oraz Wytyczne dla autorów i zasady wprowadzania danych o publikacjach. Dotychczasowe formularze zgłoszeniowe odpowiadające trzem podstawowym rodzajom publikacji zastąpiono zgłoszeniami według publikacji zaliczanych do osiągnięć naukowych i twórczych dla jednostek z grupy nauk o życiu oraz nauk humanistycznych i społecznych (rys. 3). W opracowanych Wytycznych dla autorów szczegółowo zostały przedstawione zasady gromadzenia i rejestracji danych w bazie. Określono w nich m.in. przyjęte zasady punktacji, charakterystyki formalne i merytoryczne dokumentów. Jednocześnie stopniowo zmieniana była struktura bazy:

— wprowadzono nowy format opisu bibliograficznego: redakcja czasopisma,

- w istniejących formatach dodane zostały pola dla numeru DOI, wielkości pracy w arkuszach wydawniczych, numeru kontrolnego z katalogu biblioteki,

- w odpowiednich formularzach wprowadzono pole e-ISBN i e-ISSN,

- zmieniono format opisu bibliograficznego patentu.

23 września 2013 r. ukazało się Zarządzenie Rektora Uniwersytetu Przyrodniczego w Poznaniu w sprawie obowiązku przekazywania publikacji pracowników do Biblioteki Głównej. Od tej pory „Wydruk z bazy: Bibliografia Publikacji Pracowników Uniwersytetu Przyrodniczego w Poznaniu stanowi dokument potwierdzający informacje o dorobku naukowym pracowników, uczestników studiów doktoranckich i emerytowanych pracowników Uczelni” oraz „zestawienie publikacji przygotowane przez Bibliotekę jest podstawą do oceny parametrycznej pracownika, doktoranta lub jednostki organizacyjnej Uczelni (Wydziału) w zakresie działalności naukowej”3. Pierwszeństwo rejestracji opisów bibliograficznych

${ }^{2}$ Polska Bibliografia Naukowa - pytanie o możliwość importu danych. Od: Wojciech Fenrich, Do: Olimpia Małecka [e-mail 10.12.2012]. Korespondencja osobista.

${ }^{3}$ Zarządzenie nr 142/2013 Rektora Uniwersytetu Przyrodniczego w Poznaniu z dnia 26 września 2013 r. w sprawie obowiązku przekazywania publikacji pracowników do Biblioteki Głównej UP w Poznaniu, http://portal.puls.edu.pl/sites/default/files/Zarz\%C4\%85dzenie\%20Rektora\%20nr\%20 


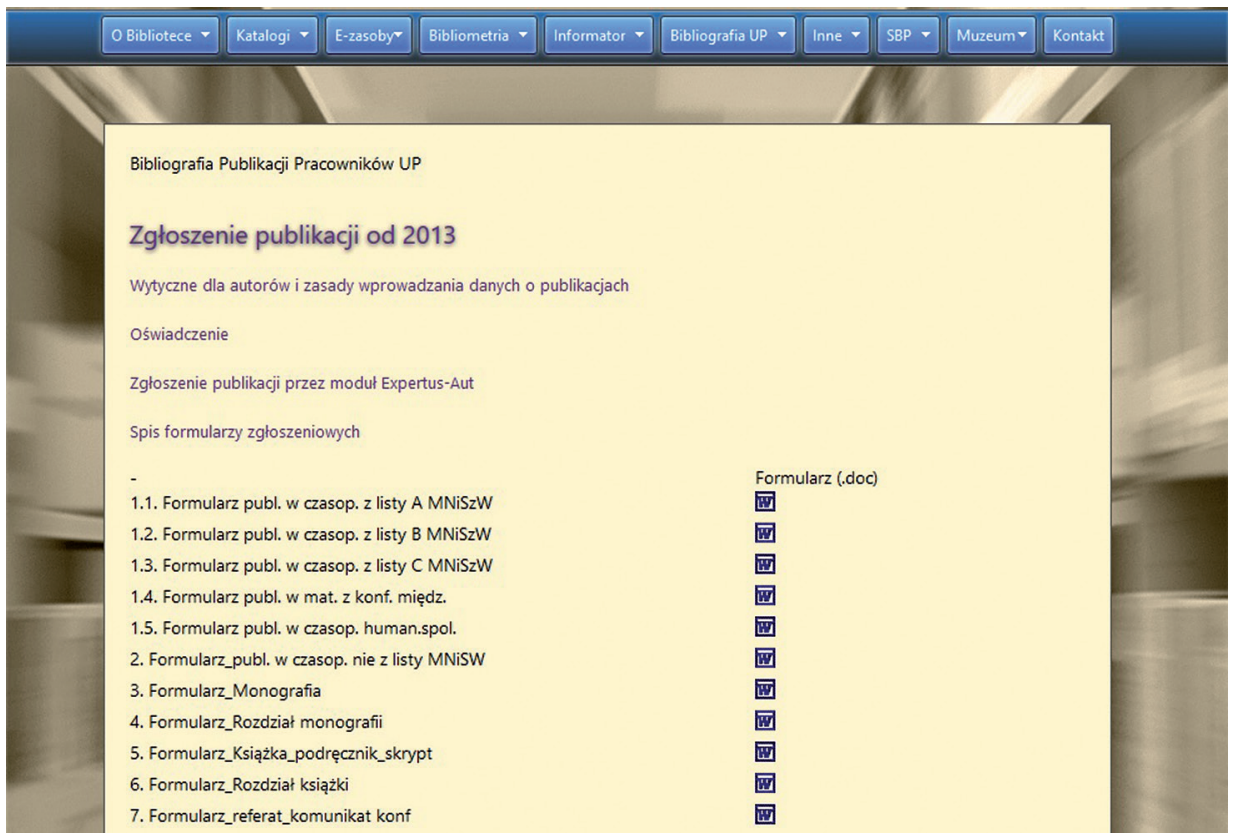

Rys. 3. Nowe formularze zgłoszeniowe

Źródło: http://bg.up.poznan.pl/bg/dzialy/bibliografia/zgloszenie_publikacji.php [dostęp: 26.06.2014].

otrzymały prace z 2013 r., które stanowią początek kompletowania danych na potrzeby przyszłej oceny jednostek naukowych. W celu zapewnienia prawidłowej obsługi bazy i umożliwienia późniejszego eksportu danych otrzymaliśmy zgodę na zakup dodatkowych części systemu Expertus:

- modułu Expertus-OPI - umożliwiającego transport danych do systemu Ankieta Jednostki/POL-on,

- modułu Expertus-Aut — internetowe zgłaszanie prac przez autorów indywidualnie lub zbiorczo przez jednostki (np. katedry) wraz z możliwością korekty zgłoszeń oraz przesyłaniem załączników w formacie .pdf,

- modułu historii struktury organizacyjnej uczelni.

Jesienią 2013 r. przystąpiono do prac związanych z wdrożeniem modułu Expertus-Aut, służącego do zgłaszania publikacji. Wprowadzone przez moduł dane przesyłane są do tzw. poczekalni, z której zostają pobrane do bazy Bibliografia, a następnie, po korekcie, udostępniane na serwerze. Moduł ten zastępuje stare formularze www (rys. 2). Rejestracji danych przez moduł mogą dokonywać tylko osoby upoważnione (posiadacze konta). W celu uporządkowania zgłoszeń przyjęte zostały zasady:

142_2013\%20w\%20sprawie\%20obowi\%C4\%85zku\%20przekazywania\%20publikacji\%20pracownik\%C3\%B3w\%20do\%20Biblioteki\%20G\%C5\%82\%C3\%B3wnej\%20UP\%20w\%20Poznaniu.pdf [dostęp: 13.07.2016]. 
— publikację zgłasza katedra, w której zatrudniony jest pierwszy autor,

— katedrze przydziela się jeden dostęp do modułu Expertus-Aut, a w przypadku instytutów możliwe jest założenie kont dla jego zakładów.

W pełnej funkcjonalności moduł został uruchomiony w styczniu 2014 r. (rys. 4).

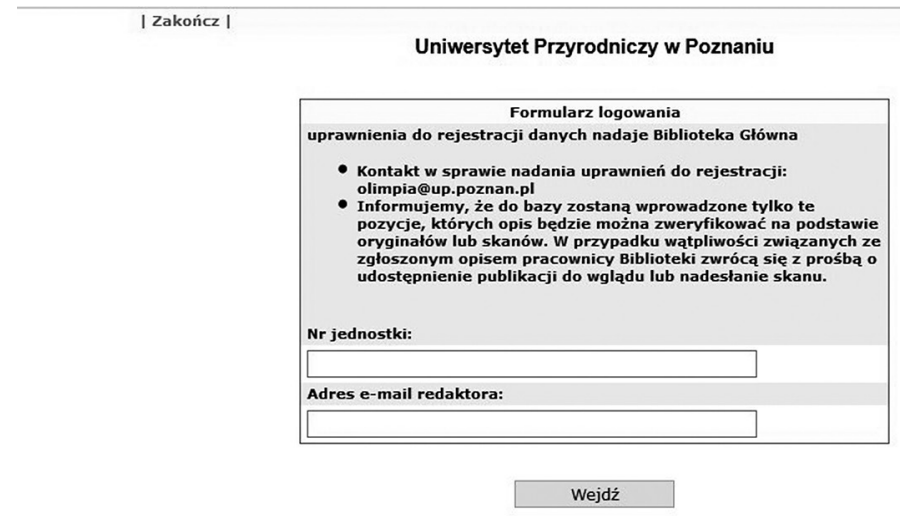

Rys. 4. Dostęp do modułu Expertus-Aut

Źródło: http://uppoz.expertus.com.pl/pubmarc.php [dostęp: 16.11.2015].

Moduł ten stanowi doskonałe uzupełnienie tradycyjnych sposobów zgłaszania publikacji (dostarczenia/wypożyczenia oryginału pracy lub wypełnienia odpowiedniego formularza zgłoszeniowego).

Kolejne zmiany w bazie Bibliografia zostały przeprowadzone po wejściu w życie ustawy z 15 stycznia 2015 r. o zmianie ustawy o zasadach finansowania nauki. Według tej ustawy dane o publikacjach od 1 stycznia 2013 r. powinny zostać zamieszczone w Polskiej Bibliografii Naukowej do 24 sierpnia 2015 r. $^{4}$ W celu terminowego przekazania danych wdrożona została wersja systemu Expertus z nowym modułem Expertus-OPI, który miał zapewnić eksport danych do PBN. Prace związane z przygotowaniem danych do eksportu do PBN rozpoczęły się w marcu 2015 r. i obejmowały m.in.:

— uporządkowanie indeksu autorów — w tym oznaczenie formy głównej i przypisanie numeru kadrowego,

- aktualizację danych dotyczących czasopism według korekty wykazu czasopism punktowanych z dnia 27 maja 2015 r.,

— zapewnienie prawidłowych połączeń czasopism z wykazami MNiSW od roku 2013,

— wprowadzenie cech publikacji według kodów stosowanych w PBN.

${ }^{4}$ Ustawa z dnia 15 stycznia 2015 r. o zmianie ustawy o zasadach finansowania nauki oraz niektórych innych ustaw, Dz.U. 2015, poz. 249, http://www.dziennikustaw.gov.pl/du/2015/249/1 [dostęp: 13.07.2016]. 
18 maja 2015 r. została zamknięta platforma robocza PBN i nie udało się przetestować eksportu danych do niej. Na skutek opublikowania Rozporządzenia Ministra Nauki i Szkolnictwa Wyższego z dnia 29 czerwca 2015 r. w sprawie Systemu Informacji o Nauce oraz uruchomienia modułu sprawozdawczego musiała nastąpić reorganizacja struktury bazy Bibliografia oraz prac dokumentacyjnych z nią związanych. W rozporządzeniu określone zostały szczegółowe informacje o publikacjach w czasopismach naukowych, monografiach naukowych lub rozdziałach w monografiach naukowych oraz terminach ich sprawozdawania. Pod koniec lipca 2015 r. został utworzony zespół zadaniowy złożony z pracowników Biblioteki Głównej oraz wydziałów. Zadaniem tego zespołu było uzupełnianie zasobów bazy Bibliografia publikacji pracowników, aby terminowo zrealizować eksport danych ${ }^{5}$. Dopiero 7 sierpnia 2015 r. uruchomiony został moduł sprawozdawczy, który ma być jedynym oficjalnym miejscem składania informacji o publikacjach. Dotychczasowa baza PBN została zmieniona w część repozytoryjną. Moduł sprawozdawczy wymagał masowego transportu danych według nowej specyfikacji, innej niż PBN. W module rejestracyjnym naszej bazy musiały zostać dodane pola zawierające informacje:

— o otwartym dostępie do publikacji,

- o konferencjach.

Pozostałe informacje, np. DOI, adres internetowy czy objętość pracy w arkuszach wydawniczych, były już wcześniej rejestrowane w bazie. Na podstawie danych zawartych w bazie Bibliografia publikacji pracowników w dniach 27-28 października 2015 r. w Oddziale Informacji Naukowej Biblioteki przygotowane zostały 103 pliki importowe do modułu sprawozdawczego. Otrzymały je osoby odpowiedzialne za rejestrację danych w MS z poszczególnych jednostek (wydziałów), czyli tzw. importerzy wydziałowi. Do ich zadań należało przede wszystkim wgranie otrzymanych danych, a następnie weryfikacja informacji o afiliacji autorów oraz ewentualne uzupełnienie wiadomości o otwartym dostępie do publikacji czy indeksowaniu jej w bazach Web of Science Core Collection lub Scopus. Kolejne 51 plików w formacie .xml zostały przesłane importerom w styczniu $2016 \mathrm{r}$.

Do zmian w ustawach i przepisach wykonawczych dostosowane zostały również zarządzenia Rektora Uniwersytetu Przyrodniczego w Poznaniu dotyczące systemu POL-on, bibliografii publikacji pracowników i działań upowszechniających naukę. W pracach związanych z redagowaniem zarządzeń brali udział przedstawiciele Działu Organizacyjno-Prawnego, Działu Nauki, Koordynator ds. Systemu POL-on oraz kierownik Oddziału Informacji Naukowej Biblioteki Głównej. 1 lutego 2016 r. weszło w życie nowe Zarządzenie Rektora w sprawie obowiązku przekazywania publikacji pracowników, uczestników studiów doktoranckich

${ }^{5}$ Rozporządzenie Ministra Nauki i Szkolnictwa Wyższego z dnia 29 czerwca 2015 r. w sprawie Systemu Informacji o Nauce, Dz.U. 2015, poz. 944, http://www.dziennikustaw.gov.pl/ du/2015/944/1 [dostęp: 13.07.2016]. 
i emerytowanych pracowników oraz informacji dotyczących patentów i wzorów użytkowych do Biblioteki Głównej Uniwersytetu Przyrodniczego w Poznaniu' ${ }^{6}$. Aktualizacja tego zarządzenia nastąpiła 14 kwietnia 2016 r. ${ }^{7}$ po opublikowaniu Rozporządzenia MNiSW z dnia 26 stycznia 2016 r. zmieniającego rozporządzenie w sprawie Systemu Informacji o Nauce.

\section{Działania upowszechniające naukę, patenty i prawa ochronne}

We wrześniu 2013 r. Bibliotece zostały powierzone zadania rejestracji w systemie POL-on danych związanych z działalnością upowszechniającą naukę (informacji o konferencjach naukowych, nagrodach i wyróżnieniach) oraz o patentach i wynalazkach. Zarządzenie nr 159/2013 Rektora Uniwersytetu Przyrodniczego w Poznaniu zobowiązywało pracowników do przekazywania tych informacji Bibliotece ${ }^{8}$. W celu zebrania potrzebnych informacji były opracowane (podobnie jak w przypadku publikacji) odpowiednie formularze, które zostały zamieszczone na stronie Biblioteki Głównej. Z tego obowiązku niestety nie udało się nam wywiązać. Powodem były przyczyny obiektywne:

— znikoma liczba zgłoszeń o konferencjach organizowanych przez jednostki, - przekazywanie niekompletnych danych,

${ }^{6}$ Zarządzenie nr 8/2016 Rektora Uniwersytetu Przyrodniczego w Poznaniu z dnia 1 lutego 2016 r. w sprawie obowiązku przekazywania publikacji pracowników, uczestników studiów doktoranckich i emerytowanych pracowników oraz informacji dotyczących patentów i wzorów użytkowych do Biblioteki Głównej Uniwersytetu Przyrodniczego w Poznaniu, http://puls.edu. $\mathrm{pl} /$ sites/default/files/Zarz\%C4\%85dzenie\%20Rektora\%20nr\%208_2016\%20w\%20sprawie\%20 obowi\%C4\%85zku\%20przekazywania\%20publikacji\%20pracownik\%C3\%B3w,\%20uczestnik\%C3\%B3w\%20studi\%C3\%B3w\%20doktoranckich\%20i\%20emerytowanych\%20pracownik\%C3\%B3w\%20\%28...\%29.pdf [dostęp: 13.07.2016].

7 Zarządzenie nr 38/2016 Rektora Uniwersytetu Przyrodniczego w Poznaniu z dnia 14 kwietnia 2016 r. w sprawie zmiany Zarządzenia nr 8/2016 Rektora Uniwersytetu Przyrodniczego w Poznaniu z dnia 1 lutego 2016 w sprawie obowiązku przekazywania publikacji pracowników, uczestników studiów doktoranckich i emerytowanych pracowników oraz informacji dotyczących patentów i wzorów użytkowych do Biblioteki Głównej Uniwersytetu Przyrodniczego w Poznaniu, http://puls.edu.pl/sites/default/files/Zarz\%C4\%85dzenie\%20Rektora\%20nr\%2038_16\%20w\%20 sprawie $\% 20$ obowi\%C4\%85zku\%20przekazywania\%20publikacji $\% 20 \% 28 \ldots \% 29 \% 20 \mathrm{do} \% 20 \mathrm{Bi}$ blioteki\%20G\%C5\%82\%C3\%B3wnej\%20UP\%20w\%20Poznaniu.pdf [dostęp: 13.07.2016].

${ }^{8}$ Zarządzenie nr 159/2013 Rektora Uniwersytetu Przyrodniczego w Poznaniu z dnia 30 października 2013 r. w sprawie przekazywania do Biblioteki Głównej UP w Poznaniu informacji dotyczących patentów i działań upowszechniających naukę, http://portal.puls.edu.pl/sites/default/ files/Zarz\%C4\%85dzenie\%20Rektora\%20nr\%20159_13\%20w\%20sprawie $\% 20$ obowi $\%$ C4\%85zku\%20przekazywania\%20do\%20Biblioteki\%20G\%C5\%82\%C3\%B3wnej\%20UP\%20w\%20 Poznaniu\%20informacji\%20dotycz\%C4\%85cych\%20patent $\%$ C3\%B3w\%20i\%20dzia\%C5\%82a\%C5\%84\%20upowszechniaj\%C4\%85cych\%20nauk\%C4\%99.pdf [dostęp: 13.07.2016]. 
— nadsyłanie zgłoszeń udziału w konferencjach zamiast informacji o zorganizowanych konferencjach,

— zgłaszanie nagród i wyróżnień, które nie mogły zostać zarejestrowane w systemie, ponieważ nie spełniały wymagań zawartych w Rozporządzeniu Ministra Nauki i Szkolnictwa Wyższego z dnia 13 lipca 2012 r. w sprawie kryteriów i trybu przyznawania kategorii naukowej jednostkom naukowym ${ }^{9}$.

Poza tym system POL-on wymagał danych o patentach, do których nie mieliśmy dostępu. Wszystkie problemy wynikłe w trakcie prób rejestracji danych były sukcesywnie zgłaszane prorektorowi ds. nauki i współpracy z zagranicą. W trakcie obowiązywania tego zarządzenia, przez prawie dwa i pół roku, otrzymaliśmy zaledwie 16 zgłoszeń o konferencjach (w tym 5 poprawnych); 19 formularzy zgłoszeniowych dotyczących nagród i wyróżnień (w tym 3 prawidłowe) i 19 zgłoszeń patentów oraz wynalazków z lat 2013-2015. W konsekwencji Zarządzeniem Rektora nr 8/2016 z dnia 1 lutego 2016 r. zniesiony został obowiązek zgłaszania do Biblioteki Głównej informacji o patentach i działaniach upowszechniających naukę. Obecnie za rejestrację w systemie POL-on konferencji, nagród i wyróżnień odpowiedzialne są podstawowe jednostki organizacyjne (wydziały) uczelni. Natomiast kontrola nad dobrami intelektualnymi uczelni, do których należą m.in. patenty, wzory użytkowe czy prawa do odmiany, została powierzona w 2015 r. Centrum Innowacji i Transferu Technologii UP w Poznaniu ${ }^{10}$. W bazie Bibliografia publikacji pracowników mają być rejestrowane tylko podstawowe dane dotyczące patentów, otrzymywane z Centrum Innowacji i Transferu Technologii.

Oprócz dokumentowania dorobku pracowników uczelni i przygotowywania plików importowych do modułu sprawozdawczego Biblioteka jest również odpowiedzialna za aktualizację danych zawartych w module Biblioteki naukowe systemu POL-on.

\section{Pozostałe zadania}

Biblioteka Główna realizuje również inne prace związane pośrednio z systemem POL-on i Polską Bibliografią Naukową, które obejmują m.in.:

— wspomaganie pracowników w procesie wprowadzania danych publikacji do części repozytoryjnej PBN,

${ }^{9}$ Rozporządzenie Ministra Nauki i Szkolnictwa Wyższego z dnia 13 lipca 2012 r. w sprawie kryteriów i trybu przyznawania kategorii naukowej jednostkom naukowym, Dz.U. 2012, poz. 877, http://www.dziennikustaw.gov.pl/du/2012/877/1 [dostęp: 13.07.2016].

10 Zarządzenie nr 62/2015 Rektora Uniwersytetu Przyrodniczego w Poznaniu z dnia 15 czerwca 2015 r. w sprawie zasad postępowania z dobrami intelektualnymi Uniwersytetu Przyrodniczego w Poznaniu, http://portal.puls.edu.pl/sites/default/files/Zarz\%C4\%85dzenie\%20Rektora\%20 nr\%2062_15\%20w\%20sprawie \%20zasad\%20post $\%$ C4\%99powania $\% 20$ z $\% 20$ dobrami $\% 20$ intelektualnymi\%20UP.pdf [dostęp: 13.07.2016]. 
— organizację spotkań informacyjnych dla pracowników uczelni dotyczących bazy Bibliografia publikacji pracowników,

- szkolenia z zakresu użytkowania modułu Expertus-Aut,

— konsultacje $\mathrm{z}$ importerami wydziałowymi dotyczące np. danych zawartych w plikach .xml utworzonych z bazy Bibliografia,

— przekazywanie drogą mailową informacji o zmianach w systemie POL-on czy PBN,

- informowanie o szkoleniach prowadzonych przez Ministerstwo Nauki i Szkolnictwa Wyższego, Index Copernicus lub Ośrodek Przetwarzania Informacji.

\section{Wnioski}

Włączenie Biblioteki Głównej wraz z tworzoną przez nią bazą Bibliografia publikacji pracowników UP w Poznaniu w prace związane ze sprawozdawczością jednostek naukowych przyniosły pozytywne efekty zarówno dla uczelni, jak i dla rozwoju bazy, m.in.:

- nastąpił ogromny napływ danych do Bibliografii za lata 2013-2015,

— od roku 2016 poprawiła się regularność zgłoszeń publikacji,

- rozwinęła się współpraca z pracownikami jednostek uczelni w zakresie udostępniania publikacji do wglądu celem sporządzenia opisu bibliograficznego,

— wzrosła kompletność danych bibliograficznych zarejestrowanych w bazie Bibliografia,

— nadsyłane są również zgłoszenia publikacji do bibliografii retrospektywnej,

— nastąpił wzrost rejestracji opisów bibliograficznych publikacji pracowników przygotowujących się do wszczęcia postępowania o nadanie tytułu naukowego profesora, stopnia naukowego doktora habilitowanego oraz doktora.

Rezultat prowadzonych prac dokumentacyjnych widoczny jest nie tylko w ogólnie dostępnej bazie, lecz także w module sprawozdawczym - importerzy wydziałowi otrzymują pliki ze sprawdzonymi danymi. Terminowe przygotowanie tych plików było możliwe po zainstalowaniu modułu Experus-OPI, którego operator (firma Splendor) aktualizację oprogramowania przeprowadzał natychmiast po ukazaniu się nowych wytycznych. Oprócz tego gromadzone systematycznie dane mogą zostać wykorzystane do oceny jednostek naukowych za lata 2013-2016. Osiągnięcie takich efektów było możliwe dzięki współpracy z władzami uczelni, które szybko reagowały na zmieniające się przepisy, wydając odpowiednie zarządzenia, oraz umożliwiły zakup dodatkowych modułów systemu Expertus, pozwalających na rozwój bazy Bibliografia publikacji pracowników UP w Poznaniu. 


\section{Bibliografia}

Polska Bibliografia Naukowa - pytanie o możliwość importu danych. Od: Wojciech Fenrich, Do: Olimpia Małecka [e-mail 10.12.2012]. Korespondencja osobista.

Rozporządzenie Ministra Nauki i Szkolnictwa Wyższego z dnia 13 lipca 2012 r. w sprawie kryteriów i trybu przyznawania kategorii naukowej jednostkom naukowym, Dz.U. 2012 , poz. 877, http://www.dziennikustaw.gov.pl/du/2012/877/1 [dostęp: 13.07.2016].

Rozporządzenie Ministra Nauki i Szkolnictwa Wyższego z dnia 29 czerwca 2015 r. w sprawie Systemu Informacji o Nauce, Dz.U. 2015, poz. 944, http://www.dziennikustaw.gov.pl/du/2015/944/1 [dostęp: 13.07.2016].

Statut Uniwersytetu Przyrodniczego w Poznaniu. Załącznik do uchwały Senatu UP w Poznaniu nr 112/2006 z dnia 30 czerwca 2006 r. (z późn. zm.), http://portal.puls.edu.pl/sites/default/files/ Statut\%20tekst\%20jednolity.pdf [dostęp: 13.07.2016].

Ustawa z dnia 15 stycznia 2015 r. o zmianie ustawy o zasadach finansowania nauki oraz niektórych innych ustaw, Dz.U. 2015, poz. 249, http://www.dziennikustaw.gov.pl/du/2015/249/1 [dostęp: 13.07.2016].

Zarządzenie nr 142/2013 Rektora Uniwersytetu Przyrodniczego w Poznaniu z dnia 26 września 2013 r. w sprawie obowiązku przekazywania publikacji pracowników do Biblioteki Głównej UP w Poznaniu, http://portal.puls.edu.pl/sites/default/files/Zarz\%C4\%85dzenie\%20Rektora\%20nr\%20142_2013\%20w\%20sprawie\%20obowi\%C4\%85zku\%20przekazywania\%20 publikacji\%20pracownik\%C3\%B3w\%20do\%20Biblioteki\%20G\%C5\%82\%C3\%B3wnej\%20 UP\%20w\%20Poznaniu.pdf [dostęp: 13.07.2016].

Zarządzenie nr 159/2013 Rektora Uniwersytetu Przyrodniczego w Poznaniu z dnia 30 października 2013 r. w sprawie przekazywania do Biblioteki Głównej UP w Poznaniu informacji dotyczących patentów i działań upowszechniających naukę, http://portal.puls.edu.pl/sites/ default/files/Zarz\%C4\%85dzenie\%20Rektora\%20nr\%20159 13\%20w\%20sprawie\%20obowi\%C4\%85zku\%20przekazywania\%20do\%20Biblioteki\%20G\%C5\%82\%C3\%B3wnej\%20 UP\%20w\%20Poznaniu\%20informa-cji\%20dotycz\%C4\%85cych\%20patent $\%$ C3\%B3w\%20 i\%20dzia $\%$ C5\%82a\%C5\%84\%20upowszechniaj\%C4\%85cych\%20nauk\%C4\%99.pdf [dostęp: 13.07.2016].

Zarządzenie nr 62/2015 Rektora Uniwersytetu Przyrodniczego w Poznaniu z dnia 15 czerwca 2015 r. w sprawie zasad postępowania z dobrami intelektualnymi Uniwersytetu Przyrodniczego w Poznaniu, http://portal.puls.edu.pl/sites/default/files/Zarz\%C4\%85dzenie\%20Rektora\%20 nr\%2062_15\%20w\%20sprawie\%20zasad\%20post\%C4\%99powania\%20z\%20dobrami\%20 intelektualnymi\%20UP.pdf [dostęp: 13.07.2016].

Zarządzenie nr 8/2016 Rektora Uniwersytetu Przyrodniczego w Poznaniu z dnia 1 lutego 2016 r. w sprawie obowiązku przekazywania publikacji pracowników, uczestników studiów doktoranckich i emerytowanych pracowników oraz informacji dotyczących patentów i wzorów użytkowych do Biblioteki Głównej Uniwersytetu Przyrodniczego w Poznaniu, http:// puls.edu.pl/sites/default/files/Zarz\%C4\%85dzenie\%20Rektora\%20nr\%208_2016\%20 w\%20sprawie\%20obowi\%C4\%85zku\%20przekazywania\%20publikacji\%20pracownik\%C3\%B3w,\%20uczestnik\%C3\%B3w\%20studi\%C3\%B3w\%20doktoranckich\%20i\%20 emerytowanych\%20pracownik\%C3\%B3w\%20\%28...\%29.pdf [dostęp: 13.07.2016].

Zarządzenie nr 38/2016 Rektora Uniwersytetu Przyrodniczego w Poznaniu z dnia 14 kwietnia 2016 r. w sprawie zmiany Zarządzenia nr 8/2016 Rektora Uniwersytetu Przyrodniczego w Poznaniu z dnia 1 lutego 2016 r. w sprawie obowiązku przekazywania publikacji pracowników, uczestników studiów doktoranckich i emerytowanych pracowników oraz informacji dotyczących patentów i wzorów użytkowych do Biblioteki Głównej Uniwersytetu Przyrodniczego w Poznaniu, http://puls.edu.pl/sites/default/files/Zarz\%C4\%85dzenie\%20Rektora\%20nr\%20 
38 16\%20w\%20sprawie\%20obowi\%C4\%85zku\%20przekazywania\%20publikacji\%20 $\% 28 . . \% 29 \% 20 \mathrm{do} \% 20$ Biblioteki\%20G\%C5\%82\%C3\%B3wnej\%20UP\%20w\%20Poznaniu. pdf [dostęp: 13.07.2016].

\title{
Place and Tasks of the Main Library of the Poznan University of Life Sciences in arrangement university -information system for higher education POL-on
}

\author{
Summary
}

The paper presents the tasks performed in the Main Library of the Poznan University of Life Sciences, which are associated with the System of information on higher education POL-on. The leading role of the Main Library is to create and update the database Bibliography of publications of the Poznań University of Life Sciences. Collecting data in the database Bibliography was discussed here, as well as organizational solutions implemented after starting POL-on System. The scope of work related to updating the database structure and adapting it to export data to the Reporting Module of Polish Scholarly Bibliography was presented. Another task entrusted to the Main Library is to collect data entry about conferences, awards and honors, patents and protection rights and to introduce it to the POL-on system. The article also presents difficulties arising during the work and their solutions. All work was carried out in close cooperation with the University authorities on the basis of the Rector's regulations.

KEYWORDS: Poznań University of Life Sciences, Main Library of the Poznań University of Life Sciences, Information system for higher education POL-on, Reporting Module of Polish Scholarly Bibliography. 